UPI YPTK Jurnal KomTekInfo Vol. 5, No. 1, Juni 2018, Hal.127-134 ISSN :2356-0010 | eISSN :2502-8758

Copyright@2018 by LPPM UPI YPTK Padang

\title{
PENGARUH PENGETAHUAN BRAND IDENTITY, DAN CUSTOMER RELATIONSHIP DALAM MENINGKATKAN BRAND AWARENESS
}

\author{
Ahmad Vajri Rahman \\ Universitas Putra Indonesia YPTK Padang \\ e-mail: vajri.rahman@gmail.com
}

\begin{abstract}
Abstrak
Penelitian yang dilakukan untuk melihat pengaruh pengetahuan brand identity, dan customer relationship dalam meningkatkan brand aweraness pada bank kesejahteraan cabang padang adalah Metode yan g digunakan untuk mencapai tujuan yaitu melalui penelitian deskriptif kuantitatif. Instrumen pengumpul data yang digunakan dalam penelitian ini adalah: Angket lembar validasi dan realibilitas. Teknik analisis data yang digunakan adalah, analisis deskriptif, uji instrumen, dan analisis inferensial. Data hasil penelitian menunjukkan bahwa tingkat pemahaman nasabah tentang brand identity berpengaruh signifikan terhadap brand awareness yang ditunjukan dari hasil tstatistiknya yang lebih besar dari t- hitungnya $(1,96)$ yaitu 6,87 . Begitu juga dengan customer relationship berpengaruh signifikan terhadap brand awareness bank kesejahteraan Cabang padang dilihat dari hasil t-statistik nya yang lebih besar dari t-hitungnya $(1,96)$ yaitu 2,92 .
\end{abstract}

Kata kunci: Brand, Brand Identity, Customer Relationship, Brand Awareness

\section{PENDAHUL UAN}

Brand merupakan "nama, simbol, desain atau kombinasi keseluruhan yang mengidentifikasikan produk atau jasa perusahaan" (Soemanagara, 2006). Masing masing perusahaan tentulah memiliki identitas pribadi yang mampu menggambarkan produk atau jasa yang di hasilkan. Brand dapat menjadi alat bantu bagi perusahaan dalam menambah nilai atau citra terhadap perusahaan dan produknya. Oleh karena itu, brand bukan hanya sebatas pada nama semata melainkan juga berkaitan dengan reputasi dan kepercayaan Customer terhadap brand tersebut.

Dalam mensosialisasikan brand nya, perusahaan juga bekerja sama dengan pihak yang berkaitan untuk membina hubungan. Hubungan yang terjalin dengan pihak eksternal seperti media juga dapat membantu perusahaan dalam mengkomunikasikan brand untuk memberi gambaran kepada publik mengenai brand perusahaan. Dalam kegiatan komunikasi pemasaran perusahaan juga harus konsisten menggambarkan brandnya, dengan demikian realisasi janji brand mampu memberikan kepuasan bagi pelangganya. Dari situ munculah pengahargaan terhadap brand yang dapat menjadi nilai tambah bagi perusahaan.

Bank kesejahteraan Ekonomi atau dikenal Bank kesejahteraan, mulai beroperasi tanggal 27 Februari 1992 untuk meningkatkan kesejahteraan Pegawai Negeri Sipil beserta keluarganya, melalui jalinan kemitraan dengan Koperasi Pegawai Repubilk Indonesia (KPRI) dan badan usaha lainnya serta masyarakat pada umumnya.

Bank kesejahteraan didirikan di kota Padang pada tahun 2007. Bagi masyarakat umum, bank kesejahteraan masih banyak yang belum mengenal, sehingga perlu adanya promosi oleh bank kesejahteraan berupa brand identity agar lebih dikenal masyarakat kota Padang. Kepribadian merek dan identitas reputasi dapat membedakannya dari pesaing, yang menghasilkan kesetiaan dan pertumbuhan customer. Dalam bukunya, B2B Brand Management Kottler menjelaskan asosiasi brand pada umumnya adalah segala sesuatu yang menghubungkan customer dengan brand, kepribadian dan simbol brand (Kottler dan Pfoertsch, 2008). Dari penjelasan di atas, bank kesejahteraan berusaha memberikan gambaran mengenai brand nya, dengan demikian ada kejelasan gambaran yang di tangkap mengenai brand tersebut. Perubahan saat ini dilakukan secara bertahap. Pelaksanaan serempak secara birokrasi, Bank kesejahteraan melakukan sosialisasi berupa brand campaign melalui koran dan media promosi lainnya seperti brosur dan banner. Suatu brand yang sukses seringkali menempakan posisi yang unik di benak Customer (Kottler \& Pfoertsch, 2008). Penghargaan terhadap brand 
UPI YPTK Jurnal KomTekInfo Vol. 5, No. 1, Juni 2018, Hal.127-134 ISSN :2356-0010 | eISSN :2502-8758

Copyright $\odot 2018$ by LPPM UPI YPTK Padang

yang diraih oleh perusahaan menunjukan bahwa brand tersebut mendapat kepercayaan dari pelangganya. Membangun customer yang kuat adalah "investasi yang bertujuan menciptakan aset tak berwujud jangka panjang dan dengan demikian memastikan kesuksesan masa depan perusahaan". (Kottler \& Pfoertsch, 2008). Oleh karena itu bank kesejahteraan bisa memiliki modal yang kuat melalui citra brand .

Penelitian terhadap tingkat pengetahuan masyarakat ini menjadi penting untuk diteliti. Dalam bukunya yang berjudul Consumer Behavior, (Engel, 1995) menjelaskan bahwa pengetahuan konsumen merupakan keuntungan yang mendasar yang dapat diperoleh untuk mengidentifikasi kesenjangan pengetahuan konsumen. Kesenjangan pengetahuan ini tidak hanya merupakan informasi dalam ingatan konsumen saja. Dengan kata lain, dengan mengetahui tingkat pengetahuan konsumen (Debitur Bank kesejahteraan) mengenai brand Bank Kesejahteraaan, maka dapat dijadikan sebagai bahan evaluasi bagaimana penerimaan para debitur terhadap sosialisasi brand yang selama ini dilakukan oleh Bank kesejahteraan. Bank kesejahteraan Ekonomi lahir dari Koperasi Pegawai Republik Indonesia (KPRI), dan diperuntukan untuk kesejahteraan pegawai negeri, jadi brand identity bank kesejahteraan tidak terlepas dari pegawai negeri. Peran penting koperasi dapat terwujud melalui partisipasi aktif terhadap kegiatan yang diselenggarakan oleh koperasi, baik partisipasi sebagai pemilik koperasi maupun sebagai penguna jasa koperasi. Jochen Ropke (2003) menyatakan partisipasi dalam organisasi ditandai oleh hubungan identitas yang dapat diwujudkan jika pelayanan yang diberikan oleh koperasi sesuai dengan kepentingan dan kebutuhan anggotanya. Dengan demikian organisasi yang dapat meningkatkan kualitas pelayanan kepada masyarakat khususnya anggotanya selalu berfokus kepada pencapaian layanan, sehingga pelayanan yang diberikan diharapkan dapat memenuhi keinginan pelanggan baik pria maupun wanita sebab terdapat perbedaan secara anatomis dan fisiologis, ini menyebabkan pula perbedaan pada tingkah laku serta kemampuan selektif terhadap kegiatan-kegiatan yang dilakukan.

Bank kesejahteraan merupakan salah satu bank baru di kota Padang dimana brand bank kesejahteraan yang berupa brand identity yang meliputi logo, slogan, dan kisah mitra umum anggota KPRI yang didasari pada koperasi. Oleh karena itu, peneliti ingin mengetahui sejauh mana tingkat pengetahuan debitur bank kesejahteraan di Padang mengenai brand identity Bank kesejahteraan dan juga tingkat pengetahuan debitur kerelasian dengan Bank kesejahteraan, dan kesadarannya manfaat dari koperasi. dalam meningkatkan brand awareness bank..

Penelitian ini dikhususkan untuk meneliti debitur Bank kesejahteraan yakni koperasi pegawai negeri yang ada di kota Padang. Hal ini dikarenakan peneliti ingin mengetahui lebih jauh bagaimana tingkat pengetahuan koperasi mengenai brand identity, Customer relationship dengan Bank kesejahteraan yang notabennya berasal dari Koperasi Pegawai Republik Indonesia (KP-RI). Sehingga akan tercipta brand awareness Koperasi pada Bank kesejahteraan.

\section{METODE PENELITIAN}

Penelitian yang dilakukan adalah merupakan penelitian deskriptif kuantitatif yang diarahkan untuk melihat pengaruh pengetahuan brand identity, dan customer relationship dalam meningkatkan brand awareness. Didalam model analisis yang dilakukan terdapat dua model analisis yaitu dengan menceritakan input hasil pencarian untuk diolah secara statistik, untuk kemudian di analisis dan dinarasikan dengan situasi dan kondisi yang sesungguhnya. Objek penelitian adalah debitur Bank kesejahteraan cabang padang (Koperasi).

Pengumpulan data dalam penelitian ini menggunakan menggunakan metode angket atau kuisioner. Angket digunakan untuk mendapatkan data pengaruh pengetahuan brand identity dan customer relationship dalam meningkatkan brand awareness, serta metode analisis data menggunakan Partial Least Square (PLS).

\section{HASIL DAN PEMBAHASAN}

Penelitian ini menguji hubungan antara pengaruh Brand identity, dan Customer relationship terhadap Brand awareness. Respondennya adalah debitur dari bank kesejahteraan yang merupakan pengurus usaha atau unit koperasi di kota Padang. Didapatkan bahwa semua hipotesis bisa diterima karena konstruk variabel Brand identity, Customer relationship, dan Brand awareness memiliki t-value melebihi 1.96.

Tabel Uji Hipotesis / Total Effect (mean,STDEV, T-Values) 
UPI YPTK Jurnal KomTekInfo Vol. 5, No. 1, Juni 2018, Hal.127-134 ISSN :2356-0010 | eISSN :2502-8758 Copyright $\odot 2018$ by LPPM UPI YPTK Padang

\begin{tabular}{|c|c|c|c|c|c|}
\hline & Original & $\begin{array}{c}\text { Sample } \\
\text { Mean } \\
\text { Sample } \\
(\mathbf{O})\end{array}$ & $\begin{array}{c}\text { Standard } \\
\text { Deviation } \\
\text { (STDEV) }\end{array}$ & $\begin{array}{c}\text { Standard } \\
\text { Error } \\
\text { (STERR) }\end{array}$ & $\begin{array}{c}\text { T Statistics } \\
\text { (|O/STERR) }\end{array}$ \\
\hline $\begin{array}{c}\text { Brand } \\
\text { Awareness -> } \\
\text { Brand Recall }\end{array}$ & 0,927456 & 0,929269 & 0,017357 & 0,017357 & 53,435619 \\
\hline $\begin{array}{c}\text { Brand } \\
\text { Awareness -> } \\
\text { Brand } \\
\text { Recognatinition }\end{array}$ & 0,611561 & 0,611449 & 0,095600 & 0,095600 & 6,397065 \\
\hline $\begin{array}{c}\text { Brand } \\
\text { Awareness -> } \\
\text { Top of Mind }\end{array}$ & 0,880667 & 0,883756 & 0,031842 & 0,031842 & 27,657726 \\
\hline $\begin{array}{c}\text { Brand } \\
\text { Awareness -> } \\
\text { Unware of } \\
\text { brand }\end{array}$ & 0,351194 & 0,284657 & 0,272716 & 0,272716 & 1,287765 \\
\hline $\begin{array}{c}\text { Brand Identity } \\
\text {-> Brand } \\
\text { Awareness }\end{array}$ & 0,836857 & 0,830350 & 0,121707 & 0,121707 & $\mathbf{6 , 8 7 5 9 9 8}$ \\
\hline $\begin{array}{c}\text { Brand Identity } \\
\text {-> Brand } \\
\text { Recall }\end{array}$ & 0,776148 & 0,771833 & 0,115546 & 0,115546 & 6,717219 \\
\hline $\begin{array}{c}\text { Brand Identity } \\
\text {-> Brand } \\
\text { Recognatinition }\end{array}$ & 0,511789 & 0,510688 & 0,120897 & 0,120897 & 4,233262 \\
\hline $\begin{array}{c}\text { Brand Identity } \\
\text { Kemampuan }\end{array}$ & 0,932686 & 0,933050 & 0,007609 & 0,007609 & 122,583864 \\
\hline
\end{tabular}

\begin{tabular}{|c|c|c|c|c|c|}
\hline $\begin{array}{c}\text { Brand Identity } \\
\text {-> Kemampuan } \\
\text { Sharing }\end{array}$ & 0,900076 & 0,899195 & 0,014996 & 0,014996 & 60,021183 \\
\hline $\begin{array}{c}\text { Brand Identity } \\
\text {-> Kemampuan } \\
\text { mengingat }\end{array}$ & 0,930891 & 0,930093 & 0,013159 & 0,013159 & 70,739753 \\
\hline $\begin{array}{c}\text { Brand Identity } \\
\text {-> Top of Mind }\end{array}$ & 0,736992 & 0,733856 & 0,111322 & 0,111322 & 6,620366 \\
\hline $\begin{array}{c}\text { Brand Identity } \\
\text {-> Unware of } \\
\text { brand }\end{array}$ & -- & -- & 0,211732 & 0,211732 & 1,388071 \\
\hline $\begin{array}{c}\text { Costumer } \\
\text { Relationship -> } \\
\text { Brand } \\
\text { Awareness }\end{array}$ & 0,422848 & 0,408260 & 0,144632 & 0,144632 & $\mathbf{2 , 9 2 3 6 1 5}$ \\
\hline Costumer & - & - & 0,132877 & 0,132877 & 2,951390 \\
\hline
\end{tabular}


UPI YPTK Jurnal KomTekInfo Vol. 5, No. 1, Juni 2018, Hal.127-134 ISSN :2356-0010 | eISSN :2502-8758 Copyright@2018 by LPPM UPI YPTK Padang

\begin{tabular}{|c|c|c|c|c|c|}
\hline $\begin{array}{c}\text { Relationship -> } \\
\text { Brand Recall } \\
\end{array}$ & 0,392173 & 0,378770 & & & \\
\hline $\begin{array}{c}\text { Costumer } \\
\text { Relationship -> } \\
\text { Brand } \\
\text { Recognatinition }\end{array}$ & $\begin{array}{c}- \\
0,258597\end{array}$ & $\begin{array}{c}- \\
0,249770\end{array}$ & 0,097186 & 0,097186 & 2,660858 \\
\hline $\begin{array}{c}\text { Costumer } \\
\text { Relationship -> } \\
\text { Fasilitas Bank } \\
\end{array}$ & 0,728485 & 0,728476 & 0,048632 & 0,048632 & 14,979576 \\
\hline $\begin{array}{c}\text { Costumer } \\
\text { Relationship -> } \\
\text { Interior dan } \\
\text { Eksterior Bank }\end{array}$ & 0,795745 & 0,799213 & 0,022814 & 0,022814 & 34,879812 \\
\hline $\begin{array}{c}\text { Costumer } \\
\text { Relationship -> } \\
\text { Karyawan } \\
\text { yang ramah } \\
\text { dan sopan } \\
\end{array}$ & 0,919992 & 0,919967 & 0,019016 & 0,019016 & 48,378881 \\
\hline $\begin{array}{c}\text { Costumer } \\
\text { Relationship -> } \\
\text { Keamanan } \\
\end{array}$ & 0,955389 & 0,954068 & 0,008599 & 0,008599 & 111,108018 \\
\hline $\begin{array}{c}\text { Costumer } \\
\text { Relationship - } \\
\text { > Top of Mind }\end{array}$ & $\begin{array}{c}- \\
0,372388\end{array}$ & $\begin{array}{c}- \\
0,358942\end{array}$ & 0,123156 & 0,123156 & 3,023716 \\
\hline $\begin{array}{c}\text { Costumer } \\
\text { Relationship -> } \\
\text { Unware of } \\
\text { brand }\end{array}$ & 0,148502 & 0,123917 & 0,100059 & 0,100059 & 1,484138 \\
\hline
\end{tabular}

Dari tabel diatas, dapat terlihat bahwa dinyatakan adanya pengaruh positif signifikan. Dapat dilihat dari hasil tstatistiknya yang lebih besar dari 1,96 $(6,875998>1,96)$. Hal ini berarti hipotesis diterima dengan artian bahwa variabel brand identity yang terdiri dari beberapa dimensi yaitu kemampuan memberikan informasi (122,583864), kemampuan mengingat (70,739753), dan kemampuan sharing $(60,021183)$ berada diatas $>1,96$ mendukung dan benar terbukti berpengaruh signifikan terhadap variabel brand awareness.

Keadaan tersebut menunjukan bahwa pemahaman yang kuat pada identtas merek terbentuk karena adanya aktifitas berulang ulang dalam menggunakan jasa Bank kesejahteraan. Begitu seringnya nasabah berhubungan atau bermitra langsung dengan bank mendorong nasabah mengetahui secara detail berbagai atribut yang dimiliki oleh bank seperti layout, interior dan eksterior, jam beroperasi hingga berbagai atribut lainnya. Pemahaman yang kuat terhadap berbagai atribut dari merek tentu menunjukan adanya pengakuan nasabah terhadap keberadaan bank kesejahteraan. Dalam hal ini bank kesejahteraan selalu menjadi pilihan utama, dalam hal ini ingatan nasabah pada Bank kesejahteraan sangat kuat, dan tak jarang nasabah mengenal logo dan slogan yang tertera pada lambing Bank kesejahteraan.

Temuan yang diperoleh konsisten dengan penelitian Hanafi (2013) yang menemukan bahwa brand identity berpengaruh terhadap brand awareness. Didalam model analisis tersebut menunjukan bahwa semakin tinggi identitas sebuah merek akan mendorong meningkatnya kesadaran merek. Wahyuni dan Dewi (2011) yang menemukan bahwa brand identity berpengaruh positi terhadap brand awareness, temuan yang diperoleh menunjukan bahwa semakin tinggi identitas sebuah merek akan mendorong meningkatnya brand awareness. 
Dari hasil tabel diatas, dapat dinyatakan adanya pengaruh signifikan antara customer relationship dengan brand awareness. Dapat dilihat dari hasil t-statistiknya yang lebih besar dari 1,96 (2,923615>1,96). Customer relationship akan terjalin saat debitur telah merasakan kesadaran merek dari bank tersebut dengan layanan yang sudah diberikan. Hal ini berarti hipotesis diterima dan benar berpengaruh signifikan terhadap Brand Awareness.

Hasil yang diperoleh tersebut menunjukan bahwa semakin kuat nilai customer relationship didalam organisasi mendorong menguatnya nilai brand awareness dalam diri nasabah pada bank kesejahteraan. Temuan yang diperoleh tersebut menunjukan bahwa didalam lingkungan Bank kesejahteraan terjalin ikatan emosional yang tinggi antara petugas bank dengan nasabah, dalam hal ini nasabah dijadikan sebagai individu yang dimanjakan, hal tersebut ditandai dengan pelayanan yang kuat pada nasabah, selain itu bank juga memprioritas kenyamanan nasabah, keadaan tersebut mendorong munculnya ikatan atau relationship antara nasabah dengan bank. Kenyamanan yang dirasakan nasabah tentu mendorong komitmen untuk terus bertahan menggunakan jasa Bank kesejahteraan, begitu tingginya frekuensi nasabah melakukan transaksi dengan Bank kesejahteraan mendorong menguatnya nilai kesadaran merek yang dirasakan nasabah.

Temuan yang diperoleh tersebut sejalan dengan penelitian yang dilakukan oleh Hanafi (2013) yang menemukan bahwa customer relationship berpengaruh positif terhadap brand awareness. Hasil yang diperoleh konsisten dengan penelitian yang dilakukan oleh Wahyuni dan Dewi (2011) yang menemukan bahwa customer relationship berpengaruh positif terhadap brand awareness. Temuan tersebut mengisyaratkan bahwa semakin kuat implementasi customer relationship akan mendorong meningkatnya brand awareness.

\section{PENUTUP}

Penelitian ini menunjukan brand identity berpengaruh signifikan terhadap brand awareness yang dirasakan nasabah pada bank kesejahtraan cabang padang. Hasil tersebut mengisyaratkan bahwa semakin tinggi pemahaman pada identitas sebuah merek akan mendorong meningkatnya nilai brand awareness.

Customer relationship berpengaruh signifikan terhadap brand awareness yang dirasakan nasabah pada bank kesejahtraan cabang padang. Hasil yang diperoleh tersebut mengisyaratkan bahwa semakin kuat nilai customer relationship akan mendorong meningkatnya pemahaman yang kuat terhadap brand awareness yang dirasakan nasabah pada bank kesejahteraan cabang padang.

Perlu selalu menjaga dan meningkatkan pengetahuan brand identity, dan customer relationship karena sangat berpengaruh terhadap brand awareness. Perlu pembinaan terhadap bank untuk tetap setalu meningkatkan pelayanan dan fasilitas bank, karena dapat mempengaruhi brand identity, customer relationship yang berpengaruh signifikan terhadap brand awareness.

\section{DAFTAR PUSTAKA}

Engel, F. James; Roger D. Blackwell; Paul W. Miniard. 2004. Perilaku Konsumen. Jakarta: Binarupa Aksara.

Permana, R. (2013). PERANCANGAN DATA MART BAGIAN PENJUALAN MOTOR BEKAS (USED MOTOR CYCLE) PADA CV. ATLAS MOTOR. JURNAL TEKNOLOGI, 3(2).

Durianto, Darmadi, Sugiarto, dan Toni Situnjak. 2003. Strategi Menaklukan Pasar Melalui Riset Ekuitas dan Perilaku Merek. Gramedia, Jakarta.

Effendy, Onong Uchjana, (2003). Ilmu, teori, dan filsafat komunikasi. Bandung: PT. Citra Aditya Bakti.

Engel, James. F; Roger.D, Blackwell and Paul. W, Miniard. (1994). Perilaku konsumen. Eight edition. United State of Amerika: Dryden Press Harcourt brace College Publisher. 
UPI YPTK Jurnal KomTekInfo Vol. 5, No. 1, Juni 2018, Hal.127-134 ISSN :2356-0010 | eISSN :2502-8758

Copyright@2018 by LPPM UPI YPTK Padang

Gelder, Sicco van. (2005). Global Brand Strategy : Unlocking Branding Potential Across Countries, Cultures \& Markets. Kogan Page Limited, London.

Gujarati, Damodar. 2003. Econometrica. McGraw-Hill. Irwin.

Georgory, James. R . The Best Of Branding.: Best practice in corporate branding. New York: The Mc Graw-Hill Companies.

Hanafi Yulianto. (2013). Pengaruh Brand Identity dan Customer Relationship Marketing Terhadap Brand Equity. Jurnal Manajemen Volume 3 Nomor 1. Universitas Brawijaya, Malang.

Hair Joseph F, William C Black, Barry J Babin, Rolp E Anderson. (2010). Multivariate Data Analysis Data Analisys. Pearson. Prentice-Hall.

Hurlock, Elizabeth. (1995). Psikologi Perkembangan. Jakarta. : Erlangga.

Istijanto. (2005). Analisis Riset Pemasaran. Jakarta. Gramedia Pustaka.

Ikrar Mohamad Saleh, Ridwan dan M Nella (2011). Hubungan antara Pengetahuan Merek Sozis dengan Volume Pembelian Produk Sosis Merek Sozzis pada PT Carrefour Cabang MTC Karebosi Makasar. Jurmal Ekomnomi Volume 4 Nomor 2.

Kotler, Philip \& Waldermar Pfoertsch, (2006). B2B Brand Management. Berlin:Springer

Kottler, Philip, Amstrong Garry. (2005). Marketing. Jakarta : PT. Bhuana Ilmu Populer.

Kotler Philip dan Keller Lane Kevin. (2010). Marketing Management 14th. Library of Congress Catalog in Publication Data Prentice Hall, Pearson.

Krisyantono, Rachmat. (2006). Teknik Praktis Riset Komunikasi. Jakarta: Kencana Prenada Media Group.

Lukas Admaja. (2010). Metodologi Penelitian Bisnis, Jakarta. BPFE, Yogyakarta.

Mohamad Syafei dan Suryadi (2012). Faktor Faktor yang Mempengaruhi Brand Awaereness Pasta Gigi Peoneer Merek Pepsoden (Pada Konsumen di Kota Semarang). Jurnal Manajemen Volume 2 Nomor 4. Semarang: Universitas Dipenegoro.

Mowen, John C; Michael Minor. 2008. Consumer Behavior 6ed. New Jersey: Prentice-Hall,Inc.

Nally Mc, David. Speak, Karl D. (2004). Be Your Own Brand. Jakarta : Gramedia Pustaka Utama

Peter, J. P., Olson. J. C., (1999). Perilaku konsumen dan strategi pemasaran, Edisi keempat (terjemahan). Jakarta : Erlangga. 
UPI YPTK Jurnal KomTekInfo Vol. 5, No. 1, Juni 2018, Hal.127-134 ISSN :2356-0010 | eISSN :2502-8758

Copyright@2018 by LPPM UPI YPTK Padang

Petter C Hansel (2011). Corelation of customer marketing relationship to brand awareness (empirical study of active used Nokia). Asian Journal Number 4 Vol 3 Singapore.

Purnama, M.L. (2002). Strategic Marketing Plan. Jakarta: Gramedia.

Gusman, AP, Verdian, I., \& Efnita, T. (2017). FUZZY LOGIC MENENUKAN STRATEGI PEMASARAN UMKM (USAHA MIKRO KECIL MENENGAH). TEKNOLOGI , 7 (2).

Rangkuty, Fredy. (2007). Metodologi dan Analisis Riset Pemasaran. Jakarta. Gramedia Pustaka.

Roslan, Rusady. (2002). Manajemen Humas dan Komunikasi. Jakarta: PT. Raja Grafindo Persada.

Roslan, Rusady. (2002). Metode penelitian Public Relations dan Komunikasi. Jakarta: PT. Raja Grafindo Persada.

Hadi, A. F. (2017). ANALISIS DATA MINING UNTUK MENENTUKAN VARIABEL-VARIABEL YANG MEMPENGARUHI KELAYAKAN KREDIT KEPEMILIKAN RUMAH MENGGUNAKAN TEKNIK KLASIFIKASI. Komputer Teknologi Informasi, 4(1).

Soemanagara Kennedy, John. E; R Dermawan 2006. Marketing Communication - Taktik dan Strategi. Jakarta. PT Buana Ilmu Populer (kelompok Gramedia)

Sumarwan Ujang, Toni Sitinjak, Fachrudin, dan Darmadi Durianto. (2010). Management Strategic. Semarang. Badan Penerbit Universitas Dipenegoro. 